\title{
編集委員会からの重要なお知らせ （刊行期日・投稿論文締切期日の変更）
}

本号は 17 巻 2 号ですが, 19 巻 1 号からこの機関誌の刊行期日が変更され, それに伴い論文 投稿の締切期日屯変更になります（変更理由はニューズレター 35 号 19 ページ参照）。この変 更により, 19 巻 1 号の投稿締切は 2006 年 8 月末となり, 18 巻 2 号の投稿締切 (2006 年 6 月 1 日）の 3 力月後となりますので, 十分ご注意ください。この変更を機に，学会員のみなさま からのいっそう多くの投稿を持待ちしています。

詳細は, 下表のと抽です。

『家族社会学研究』の刊行スケジュールと投稿締切期日

\begin{tabular}{|c|c|c|c|c|c|}
\hline \multirow{3}{*}{$\begin{array}{l}\text { 現 } \\
\text { 行 }\end{array}$} & 巻 & 17 巻 1 号 & 17 巻 2 号 & 18 巻 1 号 & 18 巻 2 号 \\
\hline & 原稿締切月日 & 2004 年 12 月 1 日 & 2005 年 6 月 1 日 & 2005 年 12 月 1 日 & 2006 年 6 月 1 日 \\
\hline & 刊行予定月日 & 2005 年 7 月末日 & 2006 年 1 月末日 & 2006 年 7 月末日 & 2007 年 1 月末日 \\
\hline \multirow{3}{*}{$\begin{array}{l}\text { 変 } \\
\text { 更 }\end{array}$} & \multirow{3}{*}{ 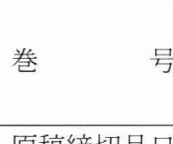 } & 19 巻 1 号 & 19 巻 2 号 & 20 巻 1 号 & 20 巻 2 号 \\
\hline & & 変更後 1 号 & 変更後 2 号 & 変更後 3 号 & 変更後 4 号 \\
\hline & & & & 次期体制 1 号 & 次期体制 2 号 \\
\hline \multirow{2}{*}{ 後 } & 原稿締切月日 & 2006 年 8 月末日 & 2007 年 2 月末日 & 2007 年 8 月末日 & 2008 年 2 月末日 \\
\hline & 刊行予定月日 & 2007 年 4 月末日 & 2007 年 10 月末日 & 2008 年 4 月末日 & 2008 年 10 月末日 \\
\hline
\end{tabular}

\section{訂 正}

本誌 Vol. 17, No. 1 に以下の詋りがありました。関係者各位ならびに会員様にご迷惑を拈掛けすることに なりました。お詫びするとともに，訂正させていただきます。

-p. 56 書評

書名

『希望格差社会一「負け犬」の絶望感が日

本を引き裂く一』

$\rightarrow$ 『希望格差社会一「負け組」の絶望感が日

- p. 65 文献紹介

左 1 行目 10 名

左 30 行目 徐安暎

左 33 行目 第 1 章 下名代中国家族への視点

右 2 行目 第 4 章 性別役割分掌の地域比較 本を引き裂く一』

$\rightarrow \underline{\underline{15}}$ 名

$\rightarrow$ 徐安其

$\rightarrow$ 第 1 章 現代中国家族への視点

$\rightarrow$ 第 4 章 性別役割分業の地域比較 